Estuarine, Coastal and Shelf Science

January 2018, Volume 200, Pages 371-379

http://dx.doi.org/10.1016/i.ecss.2017.11.030

http://archimer.ifremer.fr/doc/00412/52327/

(c) 2017 Elsevier Ltd. All rights reserved.

\title{
Benthic metabolism over the emersion - Immersion alternation in sands colonized by the invasive Manila clam Ruditapes philippinarum
}

\author{
Migné Aline ${ }^{1,{ }^{*}}$, Trigui Rima Jihane ${ }^{2}$, Davoult Dominique ${ }^{1}$, Desroy Nicolas ${ }^{2}$ \\ ${ }^{1}$ Sorbonne Universités, UPMC Univ Paris 06, CNRS UMR 7144 AD2M, Station Biologique, F-29680 \\ Roscoff, France \\ 2 IFREMER, Laboratoire Environnement et Ressources Bretagne Nord - Station de Dinard, F-35800, \\ Dinard, France \\ * Corresponding author : Aline Migné, email address : migne@sb-roscoff.fr
}

\begin{abstract}
:
The effect of an invasive infaunal suspension-feeding bivalve, the Manila clam Ruditapes philippinarum, on benthic inorganic carbon and nutrient fluxes was examined through in situ incubations. Measurements were performed in spring and summer on a tidal sandflat of the Rance estuary (south part of the Western English Channel) colonized by the Manila clam after its deliberate introduction in the 1990 's. Benthic inorganic carbon fluxes were measured using light and dark benthic chambers both at emersion and immersion. Benthic nutrient fluxes were measured using dark benthic chambers at immersion. Inorganic carbon (IC) and ammonium sediment release under darkness at immersion reached $5.60 \mathrm{mmol} \mathrm{m}^{-2} \mathrm{~h}^{-1}$ and $441 \mu \mathrm{mol} \mathrm{m}{ }^{-2} \mathrm{~h}^{-1}$ respectively for a clam density of $291 \mathrm{ind} \mathrm{m}^{-2}$. The sediment IC-release under darkness was lower during emersion than during immersion, probably due to the reduced activity of infauna at low tide. Under ambient light, a sediment IC-uptake was systematically measured at emersion, indicating a net autotrophy under the condition of measurements $(125<$ surface PAR $<1670 \mu \mathrm{mol} \mathrm{m}{ }^{-2} \mathrm{~s}^{-1}$ ), while either sediment IC-uptake or release was measured at immersion according to light variation $\left(20<\right.$ underwater PAR $\left.<990 \mu \mathrm{mol} \mathrm{m} \mathrm{m}^{-2} \mathrm{~s}^{-1}\right)$. The highest gross community primary production, calculated from highest IC-fluxes at light (i.e. net community production) and highest IC-fluxes at dark (i.e. community respiration), was similar at emersion and immersion and reached $6.2 \mathrm{mmolC} \mathrm{m} \mathrm{m}^{-2} \mathrm{~h}^{-1}$. These results suggest that the metabolic activity of the invasive Manila clam Ruditapes philippinarum contributes to increase inorganic $\mathrm{C}$ and ammonium sediment release. These regenerated nutrients may support microphytobenthic production which appeared particularly high on this intertidal sand flat.
\end{abstract}

Keywords: Benthic fluxes, Benthos, Inorganic carbon, Nutrients, Suspension-feeding bivalve, Tidal flats, France, Western english channel 


\section{Introduction}

Introduction of exogenous species concerns all ecosystems and is considered as one of the most serious threats on the conservation of natural biodiversity. In marine areas, accidental introductions increase inexorably with shipping traffic, and add to deliberate introductions for aquaculture (Carlton and Geller 1993). Locally, the introduction of exogenous species may simply result in the addition of a new species, without apparent effect on autochthon communities (Reise et al. 2006). Introduced species may also proliferate (becoming invasive) and profoundly change the local diversity (by competitive exclusion of native species, through habitat modification, etc.) and strongly influence ecosystem functioning (Ruiz et al. 1997). The infaunal suspension-feeding bivalve Ruditapes philippinarum, indigenous to sub-tropical and temperate coastal waters of the western Pacific and Indian oceans, has been purposefully introduced in Europe from the 1970s (Chiesa et al. 2017) because of its high commercial value as seafood species. Initially reared in areas spatially limited, the Manila clam rapidly spread and has established naturalised populations (Humphreys et al. 2015). In several disturbed estuaries or lagoons, the Manila clam has supplanted the European native carpet shell clam Ruditapes decussatus by occupying almost entirely its ecological niche (Bidegain et al. 2015).

Suspension-feeding bivalves are recognized to play an important role in benthic-pelagic coupling in many coastal ecosystems by removing particles from the water column and transferring undigested material in their biodeposits to the sediment surface (Newell 2004). R. philippinarum has been shown to produce large amounts of faeces and pseudofaeces (Han et al. 2001). In sediments in which the species is farmed, organic matter enrichment has been observed (Nizzoli et al. 2011) and sediment-water column fluxes of dissolved materials have been suggested to be stimulated through bacterial mineralisation of biodeposits (Bartoli et al. 2001). Infaunal species also stimulate sedimentwater column fluxes through their bioturbation (Welsh 2003) and influence the pathways of nutrient recycling through associated bacteria (e.g. Welsh and Castadelli 2004). The role of $R$. philippinarum in stimulating ammonium release from the sediment is well documented (Magni and Montani 2006; Nizzoli et al. 2011; Stief 2013; Welsh et al. 2015). Farmed Manila clams have also been shown to modify nitrate and nitrite fluxes, stimulating both nitrification and nitrate reduction, (Nizzoli et al. 2006b; Welsh et al. 2015) and to influence phosphorous recycling (Nizzoli et al. 2006a). Macrofauna also directly influences benthic fluxes through its metabolism: inorganic carbon is released through respiration and metabolic end-products, such as ammonium, are excreted to the water column. Isolated R. philippinarum individuals have been shown to exhibit high rates of respiration and 
ammonium or phosphate excretion (Magni et al. 2000; Welsh et al. 2015). This direct influence is likely to be density dependent. However, suspension-feeding by reducing water column turbidity may increase light penetration to the sediment surface and stimulate microphytobenthos production which in turn may reduce the nutrient efflux from the sediment (Newell 2004). In support of this, stimulation of intertidal microphytobenthic production at higher densities of suspension-feeding bivalves was shown by field manipulation of the New Zealand cockle (Austrovenus stutchburyi) density (Sandwell et al. 2009). However, the analysis of compiled data from nine estuaries in the North Island of New Zealand led to a weak linkage between cockle abundance and primary production (Pratt et al. 2014a). Indeed, interactions between suspension-feeding bivalves and microphytobenthos imply complex relationships among benthic and pelagic processes that depend of environmental conditions.

There is then still a need for field studies to evaluate in situ influences of natural dense infauna populations on benthic metabolism (Welsh 2003). In particular, there is a need to consider the metabolism of intertidal populations in the two contrasting environments they are alternatively exposed to (air and sea water). So far published studies on the influence of Ruditapes philippinarum on benthic fluxes concerned mainly shallow water populations (e.g. Welsh et al. 2015) and the few studies dealing with intertidal populations were based only on underwater measurements (e.g. Magni et al. 2000). In this context, the present study aimed to examine the effect of $R$. philippinarum on inorganic carbon fluxes in colonized intertidal sand flat, both at emersion and immersion. For that purpose, light and dark benthic chambers were used in situ and without any manipulation, during two seasons. The effect of $R$. philippinarum on dissolved nutrient fluxes was also examined in dark incubations at immersion. It was intended (1) to investigate the effect of clam density on benthic metabolism, (2) to provide an estimate of primary production, and (3) to compare aerial and underwater benthic metabolism.

\section{Materials and Methods}

\subsection{Study site}

Measurements were performed in a mid-tidal sand flat of the upstream Rance estuary $\left(48^{\circ} 52^{\prime} \mathrm{N}\right.$, $1^{\circ} 98^{\prime} \mathrm{W}$ ), located in the southern part of the western English Channel (France). This estuary is characterized by the presence of a tidal power plant at its mouth, which imposes specific tidal conditions. Alternation of tide levels are not as regular than in the open sea and there is a particularly long high water stand (Retière 1994). Tidal range varies between 4.0 and $7.0 \mathrm{~m}$ instead of $13.5 \mathrm{~m}$ in the open sea (Desroy and Retiere 2001). Mean high water level is almost unmodified while mean mid and low water levels are elevated by approximately 2.5 and $3.5 \mathrm{~m}$ respectively (Desroy 1998). The 
Manila clam Ruditapes philippinarum has been introduced in the Rance estuary at the end of the 1990's and has rapidly colonized all tidal sand flats, reaching densities of 500 ind. $\mathrm{m}^{-2}$ in the upstream part in 2002 (unpublished data from the Museum National d'Histoire Naturelle).

\subsection{Sampling strategy}

Benthic metabolism was measured during neap tides, with morning low tide, in summer (July 2010) and spring (April 2011). In July 2010, two stations were selected as being located at the same tidal level (about $8 \mathrm{~m}$ above chart datum) and as being, a priori, characterized by contrasted density of Ruditapes philippinarum. The two stations ( $\mathrm{A}$ and $\mathrm{B}, 20 \mathrm{~m}$ apart) were investigated during two following days (A: July 05, B: July 06). At each station, three benthic chamber cores were positioned about $2 \mathrm{~m}$ apart at the beginning of emersion (predicted to occur for $8 \mathrm{~m}$ above chart datum at 8:48 the $05^{\text {th }}$ and at 9:24 the $06^{\text {th }}$ ). Successive triplicate incubations were performed to assess sedimentair inorganic carbon fluxes until flooding. The first incubation was done in darkness (after the sediment has been shaded for a while) and the 3 or 4 next were done at ambient light. At the beginning of immersion (predicted to occur at 12:06 the $05^{\text {th }}$ and at 13:24 the $06^{\text {th }}$ ), successive triplicate incubations were performed on the left standing cores to assess sediment-water inorganic carbon fluxes. Two incubations were done at ambient light and the last one was done in darkness. Nutrient fluxes were also assessed during this dark underwater incubation. Benthic chambers were opened at the end of each incubation, to allow complete air or seawater replenishment before the beginning of a new incubation. The sediment isolated by each core was sampled during the following ebb tide for macrofauna identification and counting and subsamples of each core were used for sediment characterization. In April 2011, the same investigation (except for the sediment characterization) was done on two other stations situated $150 \mathrm{~m}$ apart from the stations visited in July. The two stations ( $C$ and D, $20 \mathrm{~m}$ apart) were investigated the $11^{\text {th }}$ and the $12^{\text {th }}$ of April respectively. At these dates, the emersion of the $8 \mathrm{~m}$ level was predicted to occur at 8:06 and 8:42 respectively and its immersion at 11:18 and 13:00 respectively. During emersion, the first incubation was done in darkness and the 3 or 4 next were done at ambient light. During immersion, one or two incubations were done at ambient light and the last one was done in darkness.

\subsection{Inorganic carbon and nutrients fluxes}

Three sediment areas of $0.071 \mathrm{~m}^{2}$ were enclosed down to a $10-\mathrm{cm}$ depth using stainless-steel cores on which were later sealed acrylic hemispheres trapping a volume of $10.5 \mathrm{~L}$. Incubations were performed under darkness to estimate benthic community respiration (CR) and under natural light condition to estimate net community production (NCP, the balance between community gross primary production and community respiration). 
During emersion, $\mathrm{CO}_{2}$ fluxes were measured the sediment-air interface using the closed-chamber method described in Migné et al. (2002). Changes in air $\mathrm{CO}_{2}$ concentration (ppm) in the benthic chambers were measured with infrared gas analysers (LiCor Li-800) for 15-35 min. $\mathrm{CO}_{2}$ concentrations were recorded in data loggers (LiCor Li-1400) with a $15 \mathrm{~s}$ frequency. $\mathrm{CO}_{2}$ flux was calculated as the slope of the linear regression of $\mathrm{CO}_{2}$ concentration $\left(\mu \mathrm{mol} \mathrm{mol}^{-1}\right)$ against time $(\mathrm{min})$ and expressed in mmolC $\mathrm{m}^{-2} \mathrm{~h}^{-1}$ assuming a molar volume of $22.4 \mathrm{~L}$ at standard temperature and pressure.

During immersion, fluxes of dissolved inorganic carbon (DIC) were measured th the sediment-water interface using the closed-chamber method described in Ouisse et al. (2011). Seawater was collected from within the benthic chambers using $100 \mathrm{ml}$ syringes at the beginning and end of incubations (duration of incubations was ca. 60 to $80 \mathrm{~min}$ ). The $\mathrm{pH}$ was measured immediately using a combination $\mathrm{pH}$ probe with a gel-filled double junction reference and built-in temperature sensor (Hach Lange PHC101, accuracy \pm 0.002 , NBS scale, previously calibrated). Seawater samples were then passed through cellulose acetate membrane filters $(0.8 \mu \mathrm{m})$ and spiked with $\mathrm{HgCl}_{2}$ for potentiometric laboratory determination of total alkalinity, which was performed on 3 subsamples of $20 \mathrm{ml}$ (Millero et al. 1993). DIC concentration of seawater was calculated from pH, total alkalinity, temperature and salinity according to Strickland \& Parsons (1972) and using the formula given in Oviatt et al. (1986). DIC fluxes were then calculated as the difference between final and initial concentrations and expressed in mmolC $\mathrm{m}^{-2} \mathrm{~h}^{-1}$. Water was also sampled from within the benthic chambers at the beginning and end of dark incubations using $300 \mathrm{ml}$ syringes to measure nutrient concentrations with a Technicon autoanalyser (Aminot and Kérouel 2007). Ammonium $\left(\mathrm{NH}_{4}^{+}\right.$) concentrations were assessed by fluorimetry (according to Roth 1971). Nitrite $\left(\mathrm{NO}_{2}{ }^{-}\right)$, nitrate $\left(\mathrm{NO}_{3}{ }^{-}\right)$ and phosphate $\left(\mathrm{PO}_{4}{ }^{3-}\right)$ concentrations were assessed by colorimetry (according to Bendschneider and Robinson 1952; Murphy and Riley 1962; Wood et al. 1967). Nutrient fluxes were then calculated as the difference between final and initial concentrations and expressed in $\mu \mathrm{mol} \mathrm{m} \mathrm{m}^{-2}$.

\subsection{Additional measurements}

Ambient temperature $\left({ }^{\circ} \mathrm{C}\right.$ ), photosynthetically available radiations (PAR in $\mu$ mol quanta $\mathrm{m}^{-2} \mathrm{~s}^{-1}$ ) and water depth $(m)$ were recorded during incubations with a one minute frequency. Temperature was measured in air or water using an ultraminiature MDS MkV-T sensor (Alec Electronics). PAR was measured with a LiCor SA-190 flat quantum sensor in the air and with an ultra-miniature MDS MkV-L spherical sensor (Alec Electronics) underwater. Spherical sensor measurements were converted to flat surface measurements using the conversion factor of 0.571 given by Ouisse et al. (2011). Water depth was measured with an ultraminiature MDS MkV-D sensor (Alec Electronics). 
In July, at the ebbing tide following a series of incubations, sediment was collected to estimate the microphytobenthos biomass as sediment chlorophyll $a(\mathrm{chl} a$ ) content. Three cores (16 mm inner diameter, $10 \mathrm{~mm}$ depth) were sampled inside each benthic chamber core in order to take into account the heterogeneous distribution of the microphytobenthos (Spilmont et al. 2011). Chl $a$ was extracted from each $2 \mathrm{ml}$ sediment core in $8 \mathrm{ml} 90 \%$ acetone, gently mixed, stored in darkness at $6^{\circ} \mathrm{C}$ for $4 \mathrm{~h}$ and centrifuged at $4000 \mathrm{rpm}$ for $15 \mathrm{~min}$. Chl $a$ content was determined by spectrophotometry (Jeffrey and Humphrey 1975) and expressed in $\mathrm{mg} \mathrm{chl} a \mathrm{~m}^{-2}$. Sediment was also collected for grain size and organic matter content measurement. Sediment grain size was determined by wet sieving, according to the AFNOR specifications (17 sieves from 0.63 to $2500 \mu \mathrm{m}$ ) to evaluate the relative abundance (in \% dry weight) of each sediment fraction. The mean grain size was calculated according to Folk and Ward (1957). Organic matter was measured as percentage of weight loss by ignition $\left(520^{\circ} \mathrm{C}, 6 \mathrm{~h}\right)$ from the dried sediment $\left(60^{\circ} \mathrm{C}\right)$.

Finally, sediment isolated by each benthic chamber core $\left(0.071 \mathrm{~m}^{2}, 10 \mathrm{~cm}\right.$ depth) was collected and sieved (1 $\mathrm{mm}$ mesh) to sort macrofauna. Individuals were identified to the species level under a dissecting or a compound microscope and counted. The highest shell length of Ruditapes philippinarum entire individuals was measured to the nearest $0.01 \mathrm{~mm}$ using a digital caliper. After that, individuals were dried at $60^{\circ} \mathrm{C}$ for $48 \mathrm{~h}$ and then burned for $6 \mathrm{~h}$ at $520^{\circ} \mathrm{C}$ to determine their biomass as the difference between weights before and after burning (ash free dry weight, afdw) .

\subsection{Data analyses}

Wilcoxon rank tests were used to compare the various measured variables between stations at each season. With three observations per group, significant difference corresponds to a complete separation of the groups with a probability of 0.05 . The diversity of the macrofauna community was assessed for each sample using Pielou evenness index $\left(J^{\prime}\right)$. The macrofauna community was compared between samples of each season using one-way ANOSIM tests (station as factor) based on Bray-Curtis similarity using untransformed abundance data. The relationship between gross community primary production (GCP) and light (irradiance I measured as PAR) was tested according to the fit of the model of Webb et al. $\left(1974, \mathrm{GCP}=\mathrm{GCP}_{\mathrm{m}}\left(1-\mathrm{e}^{-1 / \mathrm{k}}\right)\right)$, using nonlinear least-squares estimates. The rank correlation between the sediment ammonium release in darkness and the biomass of clams was tested using the Spearman's method.

3. Results

\subsection{Ruditapes philippinarum density, biomass and size}


Ruditapes philippinarum mean density varied among visited stations from 56 to 291 ind $\mathrm{m}^{-2}$ (Figure 1a), which represented a mean biomass of 3.96 to $96.25 \mathrm{~g}_{\text {afdw }} \mathrm{m}^{-2}$ (Figure $1 \mathrm{~b}$ ). Density and biomass were significantly higher at station $A$ than station $B$ in July $(W=9, p=0.050)$ but did not differ significantly between stations $C$ and $D$ in April ( $W=3, p=0.700)$.

The mean shell length varied among visited stations from 10.02 to $35.05 \mathrm{~mm}$ (Figure 1c). Individuals were significantly larger at station $A$ than station $B$ in July $(W=373, p=0.029)$ and did not differ significantly between stations $C$ and $D$ in April $(W=190, p=0.293)$.

\subsection{Macrofauna community}

A total of 30 species of macrofauna was identified. Beside Ruditapes philippinarum, abundant species were the bivalves Abra tenuis and Scrobicularia plana, the isopod Cyathura carinata and the polychaetes Ampharete acutifrons, Heteromastus filiformis and Pygospio elegans (Table 1).

The mean number of species of macrofauna varied among visited stations from 4 to 15 and did not differ significantly between stations $A$ and $B$ nor $C$ and $D$ (Table 2). The mean density of macrofauna varied among visited stations from 1624 to 5169 ind $\mathrm{m}^{-2}$ and did not differ significantly between stations $A$ and $B$ nor $C$ and $D$ (Table 2). The mean evenness varied among visited stations from 0.58 to 0.70 and did not differ significantly between stations $A$ and $B$ nor $C$ and $D$ (Table 2). One-way ANOSIM test did not discriminate the macrofauna community of stations $A$ and $B(R=0.593, p=$ $0.100)$ nor $C$ and $D(R=-0.037, p=0.600)$.

\subsection{Sediment characterization and microphytobenthos biomass}

The sediment characteristics did not differ significantly between stations A and B visited in July 2010 (Table 3). Sediment was poorly sorted, dominated by sand (averaging 66\%) and gravel (corresponding to shell debris and averaging 34\%) and contained no mud. The mean grain size averaged $1579 \mu \mathrm{m}$. The organic matter content did neither differ significantly between stations and was low (averaging $0.70 \%$ of sediment dry weight, Table 3 ). The microphytobenthos biomass estimated as chlorophyll $a$ sediment content was significantly lower at station A (120 $\left.\pm 6 \mathrm{mg} \mathrm{m}^{-2}\right)$ than station B (182 $\pm 14 \mathrm{mg} \mathrm{m}^{-2}$, Table 3$)$.

\subsection{Benthic inorganic carbon fluxes over tidal cycles and estimation of primary production}

Air or water temperature, surface or underwater light (PAR) and depth conditions during incubations performed either at emersion or immersion are given for the four dates of measurements in table 4. Mean sediment inorganic carbon release measured under darkness varied among visited stations from 0.55 to $1.38 \mathrm{mmol} \mathrm{m}^{-2} \mathrm{~h}^{-1}$ at emersion and from 2.04 to $5.60 \mathrm{mmol} \mathrm{m}^{-2} \mathrm{~h}^{-1}$ at immersion (Figure 
2). The increase in sediment IC-release under darkness at immersion compared to emersion was significantly higher at station $A$ than $B(W=9, p=0.050)$ and did not differ significantly between stations $C$ and $D(W=2, p=0.400)$.

Under ambient light, an increasing sediment $\mathrm{CO}_{2}$-uptake was measured during emersion, while DIC flux varied from uptake to release during immersion (Figure 2). Considering a mean value for each chamber, sediment $\mathrm{CO}_{2}$-uptake at emersion did not vary significantly neither between stations $\mathrm{A}$ and $B(W=2, p=0.400)$ nor stations $C$ and $D(W=8, p=0.200)$ and $D I C$ flux at immersion did not vary significantly neither between stations $A$ and $B(W=6, p=0.700)$ nor stations $C$ and $D(W=6, p=$ 0.700).

Maximum gross community primary production $\left(\mathrm{GCP}_{\max }\right)$ calculated as the sum of maximum net community primary production ( $\mathrm{NCP}_{\max }$, corresponding to the highest measured sediment IC-uptake) and community respiration (CR) varied among visited stations from 3.75 to $6.23 \mathrm{mmolC} \mathrm{m}^{-2} \mathrm{~h}^{-1}$ at emersion and from 3.56 to $6.19 \mathrm{mmolC} \mathrm{m}^{-2} \mathrm{~h}^{-1}$ at immersion (Table 5). In July, biomass standardized gross community primary production $\left(\mathrm{GCP}_{\max } / \mathrm{Chla}\right)$ was significantly higher at station $\mathrm{A}$ than $\mathrm{B}$ both at emersion and immersion $(W=9, p=0.050)$.

GCP was also calculated for light incubations at immersion for which underwater light data was available ( $n=5$, see table 4). GCP under immersion was significantly correlated to light according to the model of Webb et al. (1974) $\left(G C P=4.89\left(1-e^{-1 / 130}\right), R_{\text {raw }}^{2}=0.941, n=5, p<0.05\right.$, Figure 3). Adding the $\mathrm{GCP}_{\max }$ measured under emersion only slightly modified the estimated parameters and increased the significance of the relationship $\left(G C P=4.87\left(1-e^{-1 / 100}\right), R_{\text {raw }}^{2}=0.947, n=9, p<0.001\right.$, Figure 3).

\subsection{Sediment- water nutrient fluxes under darkness}

Mean sediment ammonium release measured during dark incubations varied among visited stations from 27 to $441 \mu \mathrm{mol} \mathrm{m} \mathrm{h}^{-1}$ (Figure 4). Ammonium release was significantly higher at station A than B $(W=9, p=0.050)$ and did not differ significantly between stations $C$ and $D(W=3, p=0.700)$.

Nitrate plus nitrite mean fluxes varied among visited stations from a sediment release of $2 \mu \mathrm{mol} \mathrm{m}$ $\mathrm{h}^{-1}$ to a sediment uptake of $270 \mu \mathrm{mol} \mathrm{m} \mathrm{m}^{-2}$ (Figure 4). Nitrate plus nitrite flux differed significantly between stations $A$ and $B(W=0, p=0.050)$ and did not differ significantly between stations $C$ and $D$ $(W=4, p=1)$.

Phosphate mean fluxes varied among visited stations from a sediment release of $7 \mu \mathrm{mol} \mathrm{m}^{-2} \mathrm{~h}^{-1}$ to a sediment uptake of $16 \mu \mathrm{mol} \mathrm{m} \mathrm{m}^{-2} \mathrm{~h}^{-1}$ (Figure 4). Phosphate flux did not differ significantly neither between stations $A$ and $B(W=1, p=0.100)$ nor stations $C$ and $D(W=4, p=1)$. 
Pooled data from stations $A$ and $B$ showed significant correlation between sediment ammonium release and biomass of Ruditapes philippinarum $\left(n=6, r_{s}=0.829, p=0.029\right)$.

\section{Discussion}

\subsection{Effect of clam density on benthic metabolism}

To evaluate the effect of the invasive Manila clam Ruditapes philippinarum on benthic metabolism in this estuary, it was intended to compare stations with contrasted densities, at two seasons. However, clam density was assessed only at the end of measurements and differed significantly between the two stations investigated in summer but not between the two stations investigated in spring. The effect of clam density on benthic metabolism could then be discussed based only on summer measurements. Though only few data were so reliable, the consistency of results allowed trends to be highlighted. Inorganic carbon and ammonium release and nitrate plus nitrite uptake as well as gross primary production standardized to the microphytobenthos biomass were enhanced at high clam density. Sediment characteristics and macrofauna communities of the two stations have been shown to be similar and it is unlikely that other factors than clam density had controlled the observed differences. The clam densities in the six analyzed samples were well distributed in the range $0-423$ ind $\mathrm{m}^{-2}$. The maximum density in any one sample corresponded to what could be expected based on previous observations in this estuary (500 ind $\mathrm{m}^{-2}$ in 2002, unpublished MNHN data). It was low compared to more southern naturalised populations (e.g. about 1000 ind $\mathrm{m}^{-2}$ in the Venice Lagoon, Bidegain and Juanes 2013) but higher than the maximum density reported for the currently Europe's most northerly naturalised population, in Poole Harbour on the north coast of the English Channel, (156 ind $\mathrm{m}^{-2}$, Humphreys et al. 2007). The mean density observed here in the station A (291 ind $\mathrm{m}^{-2}$ ) was in the range of the densities observed in July in the control station of the farmed Goro lagoon (Italy) investigated by Nizzoli et al. (2006b). R. philppinarum individuals were present in their control station, due to natural recruitment or drift of seed from the nearby cultivated areas, with a density between 200 and 600 ind $\mathrm{m}^{-2}$.

The mean inorganic carbon $\left(5.60 \mathrm{mmol} \mathrm{m}^{-2} \mathrm{~h}^{-1}\right)$ and ammonium $\left(441 \mu \mathrm{mol} \mathrm{m} \mathrm{m}^{-2}\right)$ sediment release measured under darkness at immersion, in summer, at the station with the highest clam density (station A), was lower than the release measured by Nizzoli et al. (2006b) in their control station (about $7 \mathrm{mmol} \mathrm{m}^{-2} \mathrm{~h}^{-1}$ and $625 \mu \mathrm{mol} \mathrm{m} \mathrm{m}^{-2} \mathrm{~h}^{-1}$ respectively). This might be explained by a higher metabolic activity of smaller clams in the control station of the Goro lagoon. $R$. philppinarum fresh biomass was reported to be about $800 \mathrm{~g} \mathrm{~m}^{-2}$ in the control station of the Goro lagoon (Nizzoli et al. 2006b). Based on the average composition of individuals measured by Bartoli et al. (2001), this clam population could correspond to a biomass of about $41 \mathrm{~g}_{\text {afdw }} \mathrm{m}^{-2}$ while mean biomass was $97 \mathrm{~g}_{\text {afdw }} \mathrm{m}^{-2}$ 
in the station A of the present study. Higher inorganic carbon and ammonium releases in the control station of the Goro lagoon could also result from bacterial mineralisation of biodeposited organic matter. In the Rance macrotidal estuary, biodeposits are likely to be easily eroded due to great water movements. The sediment organic matter content was indeed particularly low $0.75 \% \mathrm{DW}$ in the station A) compared to the control station of the Goro lagoon (2.78 \% DW, Nizzoli et al. 2006b). Mean inorganic carbon and ammonium sediment release measured at station A was nevertheless higher than what was previously measured in the end of summer in the Abra alba community of the same estuary (2.2 and 1.5 fold higher respectively) and was already considered to be particularly high for temperate-climate soft bottoms (Migné et al. 2005). This suggests an important contribution of the Manila clam naturalised population to the functioning of this estuary through remineralisation.

\subsection{Primary production}

On each occasion (i.e. in the four visited stations), sediment inorganic C-uptake was measured during emersion under ambient light. This indicated a net autotrophy (gross primary production higher than respiration) under the conditions of measurements (surface PAR $>125 \mu \mathrm{mol} \mathrm{m}{ }^{-2} \mathrm{~s}^{-1}$ ). This sediment IC-uptake increased during emersion period at each station (being from 1.9 to 3.7 fold higher at the end than at the beginning of emersion). In such sandy sediments, this increase should not be ascribed to the migration of the microphytobenthos induced by the sudden light availability after the dark incubation (Consalvey et al. 2004; Cartaxana et al. 2011). At such tidal level (below mid-tide), changes in the amount and chemistry of pore water during the air exposure of sediments were not likely to have driven such increase (Migné et al. 2016 and references therein). This increase in ICuptake did not seem to be related to increase neither in temperature nor in light intensity. However, as measurements were performed during morning, the influence of sun angle variations on light penetration in sediment could not be excluded (Pinckney and Zingmark 1991). DIC fluxes measured during immersion under ambient light corresponded either to a sediment uptake, indicating a net autotrophy, or to a sediment release, indicating a net heterotrophy. Underwater gross community production was significantly related to the light intensity with an onset of light saturation of 130 $\mu \mathrm{mol} \mathrm{m} \mathrm{m}^{-2}$, which falls within the range reported for shallow (1 m depth) subtidal microalgae populations (Light and Beardall 2001). The highest sediment IC-uptake was considered to estimate maximum gross community primary production either at emersion or immersion in each station. The highest mean GCP $\max$ reached $6.2 \mathrm{mmolC} \mathrm{m}^{-2} \mathrm{~h}^{-1}$ and was measured in April (station D) at emersion or at low depth $(0.6 \mathrm{~m}$, with more than $60 \%$ of surface irradiance). This rate is in the upper range of gross community production estimates reported from intertidal soft sediments in temperate locations (Cahoon 1999) suggesting that regenerated nutrients may support the microphytobenthic production in this intertidal sand flat. 


\subsection{Aerial versus underwater benthic metabolism}

The sediment inorganic carbon release under darkness was from 1.6 to 7.2 fold lower during emersion than during immersion. This is in agreement with some previous studies which have investigated the variability of inorganic carbon benthic fluxes under darkness according to the low-/ high-tide alternations in intertidal intact unvegetated sediments (Gribsholt and Kristensen 2003; Cook et al. 2004; Migné et al. 2009). The significant difference between stations A and B in this increase in IC-release at immersion suggests a clam density effect. Macrofauna, which has been shown to contribute to the greatest part of the sediment respiration in some tidal sand flats (Dye 1981; Asmus 1982), has indeed a reduced activity at low tide. Some mesocosm experiments (Gribsholt and Kristensen 2002) has thus shown much higher increase of IC-release in inundated sediment with macrofauna than without any macrofauna. Clams stopped feeding at low tide and the IC-release was enhanced when they recommenced filter feeding at flooding. No alkalinity production, which has been proposed as an integrated measure of anaerobic processes (Cai and Wang 1998), was measured in the present study during summer incubations. Enhanced fluxes at high tide were then not likely to be due to the contribution of anaerobic processes in total carbon mineralisation, which has been shown on sediment from which the macrofauna has been removed (Faber et al. 2012).

Highest gross community primary production rates estimated here were similar at emersion and immersion. The few studies which have compared microphytobenthic primary production under different tide conditions have shown higher rates when exposed to air than underwater (Varela and Penas 1985; Pinckney and Zingmark 1991; Kwon et al. 2012). Results could, however, be highly variable notably according to particle size of sediment and water turbidity. The studies previously cited were performed in muds or muddy sands into which motile epipelic microalgae move down during flood tide. Furthermore, gross primary production under inundation has been shown to be higher in sandflats than in mudflats despite higher chlorophyll concentrations in mud (Billerbeck et al. 2007), and experimental increase in turbidity led to dramatic reduction in sandflat microphytobenthic production (Pratt et al. 2014b). The present study was performed in sand in which epipsammic microalgae attached to grains remained at the sediment surface and received enough light for photosynthesis during flood tide.

\section{Conclusions}

This study suggests that metabolic activity of the invasive Manila clam Ruditapes philippinarum contributes to increase inorganic $\mathrm{C}$ and ammonium sediment release. These regenerated nutrients may support microphytobenthic production which appeared particularly high on this intertidal sand 
flat. This study also demonstrated that gross community primary production rates may be similar during emersion and immersion periods while this issue has been poorly investigated in such intertidal sand flat.

\section{Acknowledgements}

The present study was funded by the Atlantic Area Transnational Programme (INTERREG IV) MAREN (Marine Renewable Energies). R. J. Trigui was funded by a Ifremer/MAREN post-doctoral grant. The authors gratefully acknowledge Julien Guillaudeau and Régis Gallon (MNHN - Station de biologie marine de Dinard) for diving support and Olivier-Pierre du Plessix and Emilie Rabiller (Ifremer Laboratoire Environnement et Ressources Port en Bessin) for nutrients analyses. Three anonymous reviewers are thanked for their constructive comments which contribute to improve this paper.

\section{References}

Aminot A, Kérouel $R$ (2007) Dosage automatique des nutriments dans les eaux marines : méthodes en flux continu. Ed. Ifremer, Méthodes d'analyse en milieu marin, pp 188

Asmus H (1982) Field measurements on respiration and secondary production of a benthic community in the northern Wadden Sea. Netherlands Journal of Sea Research 16: 403-413 10.1016/0077-7579(82)90046-1

Bartoli M, Nizzoli D, Viaroli P, Turolla E, Castaldelli G, Fano EA, Rossi R (2001) Impact of Tapes philippinarum farming on nutrient dynamics and benthic respiration in the Sacca di Goro. Hydrobiologia 455: 203-212 10.1023/A:1011910422400

Bendschneider K, Robinson RJ (1952) A new spectrophotometric method for the determination of nitrite in sea water. Journal of Marine Research 11: 87-96

Bidegain G, Barcena JF, Garcia A, Juanes JA (2015) Predicting coexistence and predominance patterns between the introduced Manila clam (Ruditapes philippinarum) and the European native clam (Ruditapes decussatus). Estuarine Coastal and Shelf Science 152: 162-172 10.1016/j.ecss.2014.11.018

Bidegain G, Juanes JA (2013) Does expansion of the introduced Manila clam Ruditapes philippinarum cause competitive displacement of the European native clam Ruditapes decussatus? Journal of Experimental Marine Biology and Ecology 445: 44-52 10.1016/j.jembe.2013.04.005

Billerbeck M, Roy H, Bosselmann K, Huettel M (2007) Benthic photosynthesis in submerged Wadden Sea intertidal flats. Estuarine, Coastal and Shelf Science 71: 704-716 10.1016/j.ecss.2006.09.019

Cahoon LB (1999) The role of benthic microalgae in neritic ecosystems. Oceanography and Marine Biology: an Annual Review 37: 47-86

Cai WJ, Wang Y (1998) The chemistry, fluxes, and sources of carbon dioxide in the estuarine waters of the Satilla and Altamaha Rivers, Georgia. Limnology and Oceanography 43: 657-668

Carlton JT, Geller JB (1993) Ecological roulette - The global transport of nonindigenous marine organisms Science 261: 78-82

Cartaxana P, Ruivo M, Hubas C, Davidson I, Serodio J, Jesus B (2011) Physiological versus behavioral photoprotection in intertidal epipelic and epipsammic benthic diatom communities. Journal of Experimental Marine Biology and Ecology 405: 120-127 10.1016/j.jembe.2011.05.027 
Chiesa S, Lucentini L, Freitas R, Marzano FN, Breda S, Figueira E, Caill-Milly N, Herbert RJH, Soares A, Argese E (2017) A history of invasion: COI phylogeny of Manila clam Ruditapes philippinarum in Europe. Fisheries Research 186: 25-35 10.1016/j.fishres.2016.07.024

Consalvey M, Paterson DM, Underwood GJC (2004) The ups and downs of life in a benthic biofilm: migration of benthic diatoms. Diatom Research 19: 181-202

Cook PLM, Butler ECV, Eyre BD (2004) Carbon and nitrogen cycling on intertidal mudflats of a temperate Australian estuary. I. Benthic metabolism. Marine Ecology Progress Series 280: 2538 10.3354/meps280025

Desroy N (1998) Les peuplements benthiques de substrats meubles du bassin maritime de la Rance. Evolution de la biodiversité et effets de l'activité prédatrice de Nephtys hombergii (annélide polychète) sur le recrutement. PhD Thesis. Rennes I University.

Desroy N, Retiere C (2001) Long-term changes in muddy fine sand community of the Rance Basin: role of recruitment. Journal of the marine biological Association of the United Kingdom 81: 553-564

Dye AH (1981) A study of benthic oxygen consumption on exposed sandy beaches. Estuarine Coastal and Shelf Science 13: 671-680 10.1016/s0302-3524(81)80048-5

Faber PA, Kessler AJ, Bull JK, McKelvie ID, Meysman FJR, Cook PLM (2012) The role of alkalinity generation in controlling the fluxes of $\mathrm{CO}_{2}$ during exposure and inundation on tidal flats. Biogeosciences 9: 4087-4097 10.5194/bg-9-4087-2012

Folk RL, Ward WC (1957) Brazos river bar: a study in the significance of grain size parameters. Journal of Sedimentary Petrology 27: 3-26

Gribsholt B, Kristensen E (2002) Effects of bioturbation and plant roots on salt marsh biogeochemistry: a mesocosm study. Marine Ecology Progress Series 241: 71-87 10.3354/meps241071

Gribsholt B, Kristensen E (2003) Benthic metabolism and sulfur cycling along an inundation gradient in a tidal Spartina anglica salt marsh. Limnology and Oceanography 48: 2151-2162

Han J, Zhang ZN, Yu ZS, Widdows J (2001) Differences in the benthic-pelagic particle flux (biodeposition and sediment erosion) at intertidal sites with and without clam (Ruditapes philippinarum) cultivation in eastern China. Journal of Experimental Marine Biology and Ecology 261: 245-261

Humphreys J, Caldow RWG, McGrorty S, West AD, Jensen AC (2007) Population dynamics of naturalised Manila clams Ruditapes philippinarum in British coastal waters. Marine Biology 151: 2255-2270 10.1007/s00227-007-0660-x

Humphreys J, Harris MRC, Herbert RJH, Farrell P, Jensen A, Cragg SM (2015) Introduction, dispersal and naturalization of the Manila clam Ruditapes philippinarum in British estuaries, 19802010. Journal of the marine biological Association of the United Kingdom 95: 1163-1172 $10.1017 / \mathrm{s} 0025315415000132$

Jeffrey SW, Humphrey GF (1975) New spectrophotometric equations for determining chlorophylls a, $\mathrm{b}, \mathrm{c}_{1}$ and $\mathrm{c}_{2}$ in higher plants, algae and natural phytoplancton. Biochemie und Physiologie der Pflanzen 167: 191-194

Kwon B-O, Khim JS, Park J, Ryu J, Kang S-G, Koh C-H (2012) Short-term variability of microphytobenthic primary production associated with in situ diel and tidal conditions. Estuarine Coastal and Shelf Science 112: 236-242 10.1016/j.ecss.2012.07.029

Light BR, Beardall J (2001) Photosynthetic characteristics of sub-tidal benthic microalgal populations from a temperate, shallow water marine ecosystem. Aquatic Botany 70: 9-27 10.1016/S0304-3770(00)00146-7

Magni P, Montani S (2006) Seasonal patterns of pore-water nutrients, benthic chlorophyll $a$ and sedimentary AVS in a macrobenthos-rich tidal flat. Hydrobiologia 571: 297-311 10.1007/s10750-006-0242-9 
Magni P, Montani S, Takada C, Tsutsumi H (2000) Temporal scaling and relevance of bivalve nutrient excretion on a tidal flat of the Seto Inland Sea, Japan. Marine Ecology Progress Series 198: 139-155 10.3354/meps198139

Migné A, Davoult D, Bourrand J-J, Boucher G (2005) Benthic primary production, respiration and remineralisation: in situ measurements in the soft-bottom Abra alba community of the western English Channel (North Brittany). Journal of Sea Research 53: 223-229 10.1016/j.seares.2004.12.002

Migné A, Davoult D, Spilmont N, Menu D, Boucher G, Gattuso J-P, Rybarczyk H (2002) A closedchamber $\mathrm{CO}_{2}$-flux method for estimating intertidal primary production and respiration under emersed conditions. Marine Biology 140: 865-869 10.1007/s00227-001-0741-1

Migné A, Davoult D, Spilmont N, Ouisse V, Boucher G (2016) Spatial and temporal variability of $\mathrm{CO}_{2}$ fluxes at the sediment-air interface in a tidal flat of a temperate lagoon (Arcachon Bay, France). Journal of Sea Research 109: 13-19 10.1016/j.seares.2016.01.003

Migné A, Spilmont N, Boucher G, Denis L, Hubas C, Janquin MA, Rauch M, Davoult D (2009) Annual budget of benthic production in Mont Saint-Michel Bay considering cloudiness, microphytobenthos migration, and variability of respiration rates with tidal conditions. Continental Shelf Research 29: 2280-2285 10.1016/j.csr.2009.09.004

Millero FJ, Zhang J-Z, Lee K, Campbell DM (1993) Titration alkalinity of seawater. Marine Chemistery 44: 153-165 10.1016/0304-4203(93)90200-8

Murphy J, Riley JP (1962) A modified single solution method for the determination of phosphate in natural waters. Analytica Chimica Acta 27: 31-36

Newell RIE (2004) Ecosystem influences of natural and cultivated populations of suspension-feeding bivalve molluscs: A review. Journal of Shellfish Research 23: 51-61

Nizzoli D, Bartoli M, Viaroli P (2006a) Nitrogen and phosphorous budgets during a farming cycle of the Manila clam Ruditapes philippinarum: An in situ experiment. Aquaculture 261: 98-108 10.1016/j.aquaculture.2006.06.042

Nizzoli D, Welsh DT, Fano EA, Viaroli P (2006b) Impact of clam and mussel farming on benthic metabolism and nitrogen cycling, with emphasis on nitrate reduction pathways. Marine Ecology Progress Series 315: 151-165

Nizzoli D, Welsh DT, Viaroli P (2011) Seasonal nitrogen and phosphorus dynamics during benthic clam and suspended mussel cultivation. Marine Pollution Bulletin 62: 1276-1287 10.1016/j.marpolbul.2011.03.009

Ouisse V, Migné A, Davoult D (2011) Community-level carbon flux variability over a tidal cycle in Zostera marina and Z. noltii beds. Marine Ecology Progress Series 437: 79-87 10.3354/meps09274

Oviatt CA, Rudnick DT, Keller AA, Sampou PA, Almquist GT (1986) A comparison of system $\left(\mathrm{O}_{2}\right.$ and $\mathrm{CO}_{2}$ ) and $\mathrm{C}-14$ measurements of metabolism in estuarine mesocosms. Marine Ecology Progress Series 28: 57-67 10.3354/meps028057

Pinckney J, Zingmark RG (1991) Effects of tidal stage and sun angles on intertidal benthic microalgal productivity. Marine Ecology Progress Series 76: 81-89 10.3354/meps076081

Pratt DR, Lohrer AM, Pilditch CA, Thrush SF (2014a) Changes in Ecosystem Function Across Sedimentary Gradients in Estuaries. Ecosystems 17: 182-194 10.1007/s10021-013-9716-6

Pratt DR, Pilditch CA, Lohrer AM, Thrush SF (2014b) The effects of short-term increases in turbidity on sandflat microphytobenthic productivity and nutrient fluxes. Journal of Sea Research 92: 170-177 10.1016/j.seares.2013.07.009

Reise K, Olenin S, Thieltges DW (2006) Are aliens threatening European aquatic coastal ecosystems? Helgoland Marine Research 60: 77-83 10.1007/s10152-006-0024-9

Retière C (1994) Tidal power and the aquatic environment of La Rance. Biological Journal of the Linnean Society 51: 25-36 10.1111/j.1095-8312.1994.tb00941.x

Roth M (1971) Fluorescence reaction for amino acids. Analytical Chemistry 43: 880-882 10.1021/ac60302a020 
Ruiz GM, Carlton JT, Grosholz ED, Hines AH (1997) Global invasions of marine and estuarine habitats by non-indigenous species: Mechanisms, extent, and consequences. American Zoologist 37: 621-632

Sandwell DR, Pilditch CA, Lohrer AM (2009) Density dependent effects of an infaunal suspensionfeeding bivalve (Austrovenus stutchburyi) on sandflat nutrient fluxes and microphytobenthic productivity. Journal of Experimental Marine Biology and Ecology 373: 16-25 10.1016/j.jembe.2009.02.015

Spilmont N, Seuront L, Meziane T, Welsh DT (2011) There's more to the picture than meets the eye: Sampling microphytobenthos in a heterogeneous environment. Estuarine Coastal and Shelf Science 95: 470-476 10.1016/j.ecss.2011.10.021

Stief $P$ (2013) Stimulation of microbial nitrogen cycling in aquatic ecosystems by benthic macrofauna: mechanisms and environmental implications. Biogeosciences 10: 7829-7846 10.5194/bg-107829-2013

Strickland JDH, Parsons TR (1972) A practical handbook of seawater analysis. Bulletin of the Fisheries Research Board of Canada 167: 1-311

Varela M, Penas E (1985) Primary production of benthic microalgae of the Ria de Arosa, NW Spain. Marine Ecology Progress Series 25: 111-119 10.3354/meps025111

Webb WL, Newton M, Starr D (1974) Carbon dioxide exchange of Alnus rubra: a mathematical model. Oecologia 17: 281-291 10.1007/BF00345747

Welsh DT (2003) It's a dirty job but someone has to do it: the role of marine benthic macrofauna in organic matter turnover and nutrient recycling to the water column. Chemistry and Ecology 19: 321-342 10.1080/0275754031000155474

Welsh DT, Castadelli G (2004) Bacterial nitrification activity directly associated with isolated benthic marine animals. Marine Biology 144: 1029-1037 10.1007/s00227-003-1252-z

Welsh DT, Nizzoli D, Fano EA, Viaroli P (2015) Direct contribution of clams (Ruditapes philippinarum) to benthic fluxes, nitrification, denitrification and nitrous oxide emission in a farmed sediment. Estuarine Coastal and Shelf Science 154: 84-93 10.1016/j.ecss.2014.12.021

Wood ED, Armstrong FAJ, Richards FA (1967) Determination of nitrate in sea water by cadmium copper reduction to nitrite. Journal of the Marine Biological Association of U.K. 47: 23-31 
Figure captions

Figure 1: Ruditapes philippinarum in sediment isolated by benthic chamber cores in the four visited stations (A \& B: July 2010, C \& D: April 2011). a) mean ( $\pm S E, n=3$ ) density; (b) mean $( \pm S E, n=3$ ) total biomass ; (c) mean ( $\pm S E, n=54,10,12$ and 26 respectively) shell length. Asterisks indicate a significant difference between stations with $p \leq 0.05$

Figure 2: Mean ( $\pm S E, n=3$ except for Li1 Immersion $A$ and $B$ where $n=2$ ) inorganic carbon fluxes (in $\mathrm{mmol} \mathrm{m}^{-2} \mathrm{~h}^{-1}$ ) measured in successive dark (Da) and light (Li) incubations isolating sediment over tidal cycles (emersion and immersion) in July (stations $A$ and $B$ ) and April (stations $C$ and D). Temperature, light and depth conditions during incubations are given in table 4

Figure 3: Gross community primary production (GCP) at immersion (black diamonds, $n=5$ ) and $\mathrm{GCP}_{\max }$ at emersion (white diamonds, $\mathrm{n}=4$ ) as a function of irradiance at the sediment surface $(\mathrm{I}$ as photosynthetically available radiations, PAR) and adjusted models on immersion data (solid line, GCP $\left.=4.89\left(1-\mathrm{e}^{-1 / 130}\right), \mathrm{R}_{\text {raw }}^{2}=0.941, \mathrm{n}=5, \mathrm{p}<0.05\right)$ and on pooled data for immersion and emersion (dotted line, GCP $=4.87\left(1-e^{-1 / 100}\right)\left(R_{\text {raw }}^{2}=0.947, n=9, p<0.001\right)$

Figure 4: Mean $\left( \pm \mathrm{SE}, \mathrm{n}=3\right.$ ) nutrient fluxes (in $\mu \mathrm{mol} \mathrm{m}^{-2} \mathrm{~h}^{-1}$ ) measured in underwater dark incubations isolating sediment in the four visited stations (A \& B: July 2010, C \& D: April 2011). Asterisks indicate a significant difference between stations with $p \leq 0.05$ 
Table 1: Mean ( $\pm \mathrm{SE}, \mathrm{n}=3$ ) density (ind $\cdot \mathrm{m}^{-2}$ ) of most abundant species in sediment isolated by benthic chamber cores in the four visited stations (A \& B: July 2010, C \& D: April 2011)

\begin{tabular}{lcccc} 
& \multicolumn{2}{c}{ July } & April \\
Abra tenuis & A & B & C & D \\
Ampharete acutifrons & $1340(37)$ & $2296(858)$ & 0 & 0 \\
Pygospio elegans & $99(53)$ & $643(320)$ & 0 & 0 \\
Cyathura carinata & $19(12)$ & $380(133)$ & $1075(371)$ & $1347(336)$ \\
Scrobicularia plana & $42(24)$ & $150(69)$ & $263(88)$ & $324(41)$ \\
Ruditapes philippinarum & $291(70)$ & $56(37)$ & $56(8)$ & $122(66)$ \\
Heteromastus filiformis & $507(45)$ & $1268(624)$ & 0 & 0
\end{tabular}

Table 2: Mean ( $\pm S E, n=3)$ number of species $(S)$ and density $\left(N\right.$, ind.$\left.m^{-2}\right)$ of macrofauna and corresponding evenness index $\left(\mathrm{J}^{\prime}\right)$ in sediment isolated by benthic chamber cores in the four visited stations (A \& B: July 2010, C \& D: April 2011). Wilcoxon test results (W, p) for differences between stations at each season

\begin{tabular}{ccccccccc} 
& \multicolumn{2}{c}{ July } & \multicolumn{2}{c}{ test } & \multicolumn{2}{c}{ April } & \multicolumn{2}{c}{ test } \\
& $\mathrm{A}$ & $\mathrm{B}$ & $\mathrm{W}$ & $\mathrm{p}$ & $\mathrm{C}$ & $\mathrm{D}$ & $\mathrm{W}$ & $\mathrm{p}$ \\
$\mathrm{S}$ & $15(0.9)$ & $12(2.9)$ & 6.5 & 0.506 & $5(0.0)$ & $4(0.6)$ & 7.5 & 0.197 \\
$\mathrm{~N}$ & $3869(216.7)$ & $5169(1826.1)$ & 3.0 & 0.700 & $1624(465.5)$ & $1854(347.9)$ & 3.0 & 0.700 \\
$\mathrm{~J}$ & $0.70(0.02)$ & $0.63(0.04)$ & 7.0 & 0.376 & $0.59(0.04)$ & $0.58(0.07)$ & 6.0 & 0.700
\end{tabular}

Table 3: Sediment characteristics (relative abundance (\% dry weight, DW) of gravel, sand and mud, mean grain size and organic matter (OM) content) and microphytobenthos (MPB) biomass (chlorophyll a (Chla) sediment content) in cores isolated by the benthic chambers in station A (2010 July 05 ) and $B(2010$ July 06 ). Values are mean $(S E)$ with $n=3$. Wilcoxon test results $(W, p)$ for differences between stations

$\begin{array}{lcccc} & \text { A } & \text { B } & \text { W } & \text { P } \\ \text { Sed. characteristics } & & & & \\ \text { Gravel (\% DW) } & 34.0(3.7) & 34.8(0.4) & 4 & 1.000 \\ \text { Sand (\% DW) } & 66.0(3.7) & 65.2(0.4) & 4 & 1.000 \\ \text { Mud (\%DW) } & 0 & 0 & & \\ \text { mean grain size }(\mu \mathrm{m}) & 1521(124) & 1637(86) & 3 & 0.700 \\ \text { OM (\%DW) } & 0.75(0.05) & 0.65(0.09) & 7 & 0.400 \\ \text { MPB biomass } & & & & \\ \text { Chla }\left(\mathrm{mg} \mathrm{m}^{-2}\right) & 119.7(6.4) & 181.7(13.8) & 0 & 0.050\end{array}$


Table 4: Temperature, light (PAR) and depth conditions during dark (Da) and light ( $\mathrm{Li}$ ) incubations at the four dates of measurements (values are the mean of data recorded with a one minute frequency, na $=$ not available)

\begin{tabular}{|c|c|c|c|c|c|c|c|c|c|c|c|c|c|c|c|}
\hline Station and sampling date & \multicolumn{7}{|c|}{ A (2010 July 05) } & \multicolumn{8}{|c|}{ B (2010 July 06) } \\
\hline Tide condition & \multicolumn{4}{|c|}{ Emersion } & \multicolumn{3}{|c|}{ Immersion } & \multicolumn{5}{|c|}{ Emersion } & \multicolumn{3}{|c|}{ Immersion } \\
\hline Measurement period (local time) & \multicolumn{4}{|c|}{$9: 43-11: 46$} & \multicolumn{3}{|c|}{$12: 34-16: 37$} & \multicolumn{5}{|c|}{$9: 39-11: 48$} & \multicolumn{3}{|c|}{$14: 00-17: 27$} \\
\hline Incubation & $\mathrm{Da}$ & L1 & L2 & L3 & L1 & L2 & $\mathrm{Da}$ & $\mathrm{Da}$ & L1 & L2 & L3 & L4 & L1 & L2 & $\mathrm{Da}$ \\
\hline Air or water temperature $\left({ }^{\circ} \mathrm{C}\right)$ & 17.1 & 19.0 & 20.1 & 20.6 & 21.8 & 22.0 & 22.2 & 21.8 & 25.4 & 24.9 & 24.5 & 23.9 & 22.4 & 22.2 & 22.0 \\
\hline Surface PAR $\left(\mu \mathrm{mol} \mathrm{m} \mathrm{m}^{-2}\right)$ & & 535 & 726 & 767 & 1235 & 1649 & & & 1231 & 1268 & 134 & 1377 & 1671 & 1605 & \\
\hline Underwater PAR ( $\left.\mu \mathrm{mol} \mathrm{m} \mathrm{m}^{-2} \mathrm{~s}^{-1}\right)$ & & & & & na & & & & & & & & 631 & 21 & \\
\hline Depth $(\mathrm{m})$ & & & & & 0.6 & 1.0 & 1.0 & & & & & & 0.7 & 1.1 & 1.4 \\
\hline Station and sampling date & \multicolumn{7}{|c|}{ C (2011 April 11) } & \multicolumn{8}{|c|}{ D (2011 April 12) } \\
\hline Tide condition & \multicolumn{4}{|c|}{ Emersion } & \multicolumn{3}{|c|}{ Immersion } & \multicolumn{5}{|c|}{ Emersion } & \multicolumn{3}{|c|}{ Immersion } \\
\hline Measurement period (local time) & \multicolumn{4}{|c|}{$8: 36-10: 51$} & \multicolumn{3}{|c|}{$12: 20-16: 10$} & \multicolumn{5}{|c|}{$9: 17-11: 26$} & \multicolumn{3}{|c|}{$14: 30-17: 20$} \\
\hline Incubation & $\mathrm{Da}$ & L1 & L2 & L3 & L1 & $\mathrm{L} 2$ & $\mathrm{Da}$ & Da & L1 & $\mathrm{L} 2$ & L3 & L4 & L & $\mathrm{Da}$ & \\
\hline Air or water temperature $\left({ }^{\circ} \mathrm{C}\right)$ & 10.4 & 10.7 & 11.6 & 11.3 & 13.4 & 13.6 & 13.7 & 11.8 & 12.3 & 12.1 & 12.9 & 13.2 & 13.7 & 13.8 & \\
\hline Surface PAR $\left(\mu \mathrm{mol} \cdot \mathrm{m}^{-2} \cdot \mathrm{s}^{-1}\right)$ & & 126 & 250 & 238 & 298 & 469 & & & 590 & 518 & 678 & 588 & 1559 & & \\
\hline Underwater PAR ( $\left.\mu \mathrm{mol} \cdot \mathrm{m}^{-2} \cdot \mathrm{s}^{-1}\right)$ & & & & & 157 & 124 & & & & & & & 987 & & \\
\hline Depth (m) & & & & & 0.6 & 1.0 & 1.2 & & & & & & 0.6 & 0.9 & \\
\hline
\end{tabular}

Table 5: Maximum gross community primary production $\left(\mathrm{GCP}_{\max }\right.$ in $\left.\mathrm{mmolC} \mathrm{m}^{-2} \mathrm{~h}^{-1}\right)$ calculated as the sum of maximum net community primary production $\left(\mathrm{NCP}_{\max }\right)$ and community respiration (CR) measured at emersion and immersion in the four visited stations (A \& B: July 2010, C \& D: April 2011) and biomass standardized gross community primary production ( $\mathrm{GCP}_{\max } / \mathrm{Chla}$ in mmolC $\mathrm{mgChla}^{-1} \mathrm{~h}^{-1}$ ) in stations $\mathrm{A}$ and $\mathrm{B}$. Values for $\mathrm{NCP}_{\max }$ and $\mathrm{CR}$ are the mean of the three benthic chambers (see Figure 2).

July

A

Emersion

$N C P_{\text {max }}$

$\mathrm{CR}$

$\mathrm{GCP}_{\text {max }}$

2.94

1.26

4.20

$\mathrm{GCP}_{\max } / \mathrm{Chla}$

0.04

Immersion

$\mathrm{NCP}_{\max }$

0.40

$\mathrm{CR}$

$\mathrm{GCP}_{\text {max }}$

5.60

6.00

$\mathrm{GCP}_{\max } /$ Chla
B

2.37

1.38

3.75

0.02

1.37

2.19

3.56

0.02
April

C D

$1.08 \quad 0.55$

$5.59 \quad 6.23$

1.61

2.04

3.97

3.65

6.19 

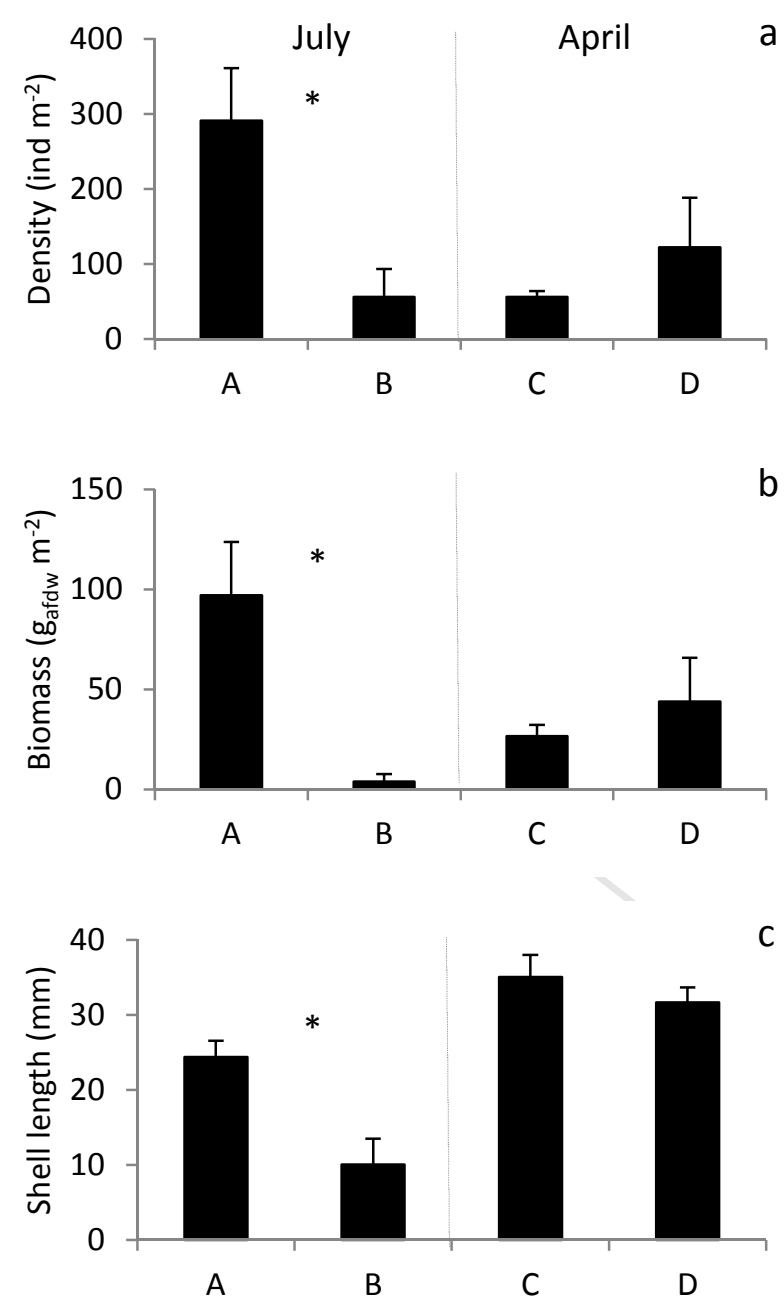

Figure 1: Ruditapes philippinarum in sediment isolated by benthic chamber cores in the four visited stations (A \& B: July 2010, C \& D: April 2011). a) mean ( $\pm S E, n=3$ ) density; (b) mean ( $\pm S E, n=3$ ) total biomass ; (c) mean ( $\pm S E, n=54,10,12$ and 26 respectively) shell length. Asterisks indicate a significant difference between stations with $p \leq 0.05$ 
A) 2010 JULY 05

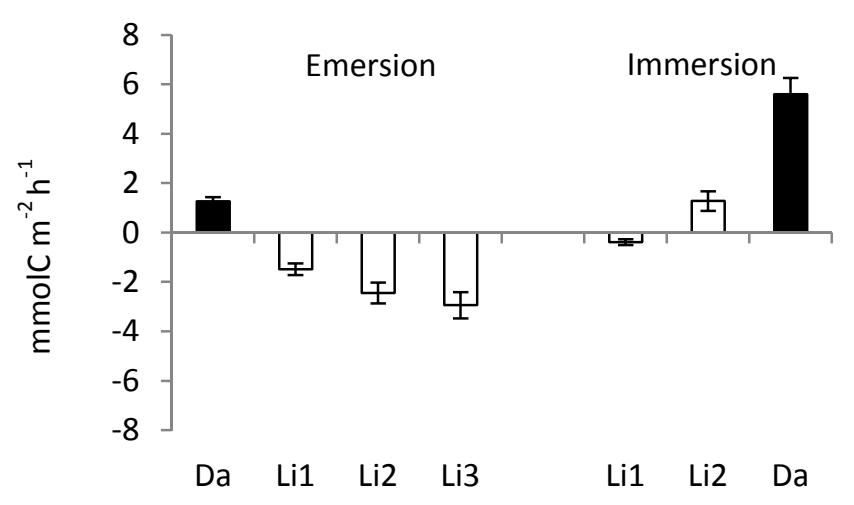

C) 2011 April 11

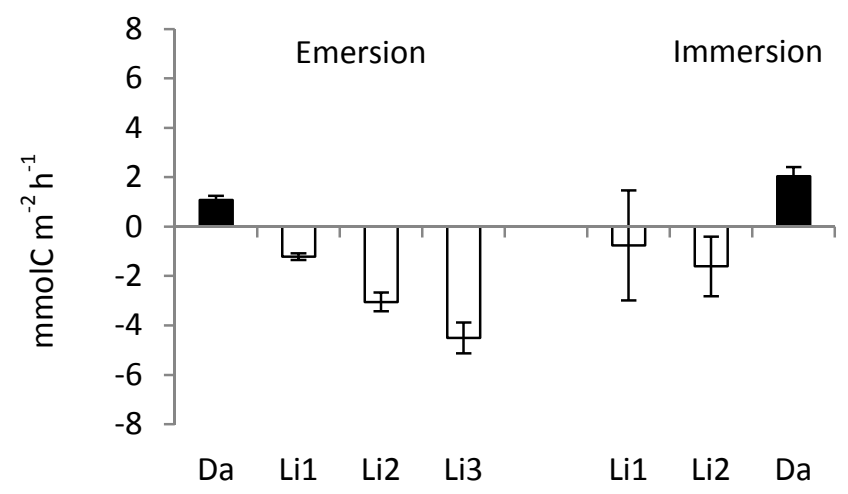

B) 2010 JULY 06

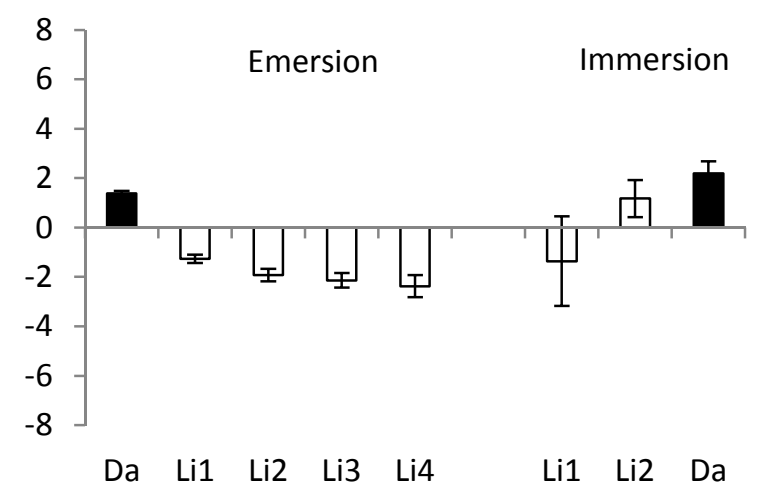

D) 2011 April 12

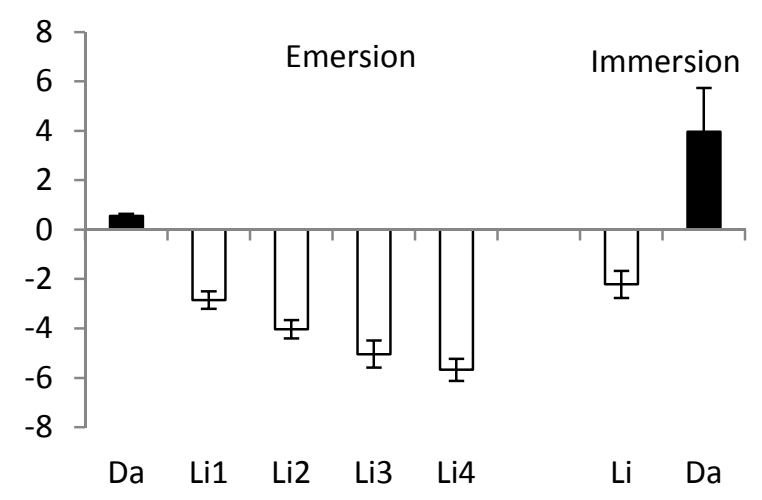

Figure 2: Mean ( $\pm S E, n=3$ except for Li1 Immersion $A$ and $B$ where $n=2$ ) inorganic carbon fluxes (in $\mathrm{mmol} \mathrm{m} \mathrm{m}^{-2}$ ) measured in successive dark (Da) and light ( $\mathrm{Li}$ ) incubations isolating sediment over tidal cycles (emersion and immersion) in July (stations $A$ and $B$ ) and April (stations $C$ and D). Temperature, light and depth conditions during incubations are given in table 4 


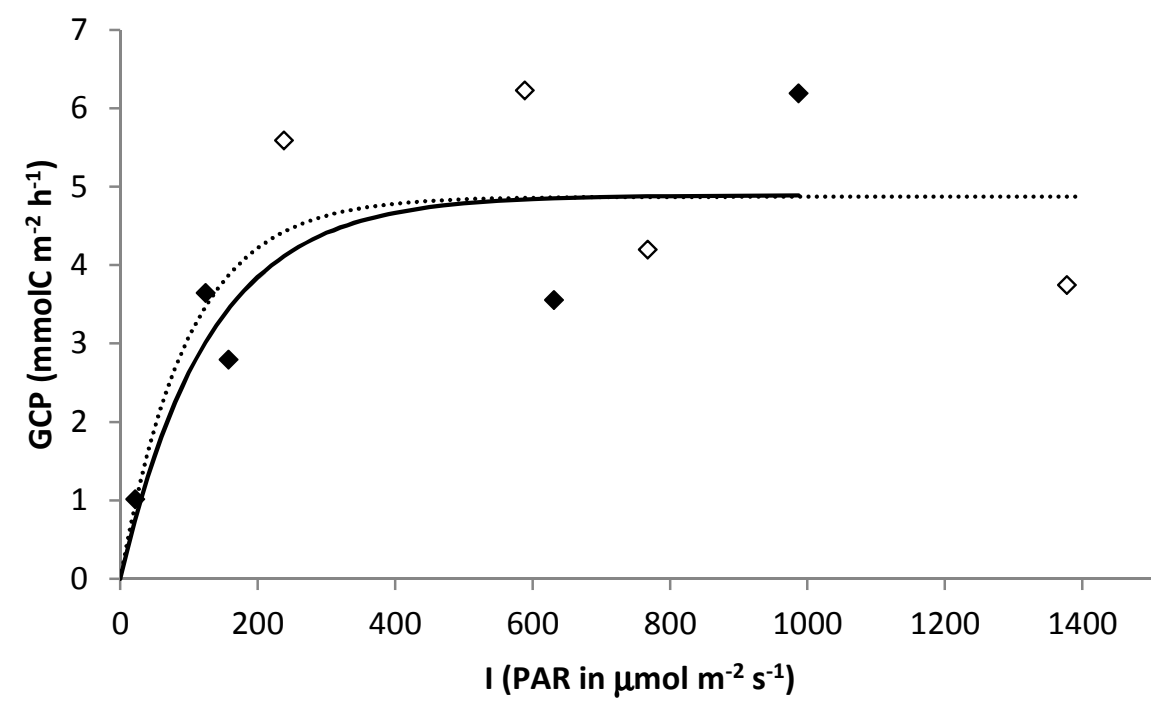

Figure 3: Gross community primary production (GCP) at immersion (black diamonds, $n=5$ ) and $\mathrm{GCP}_{\max }$ at emersion (white diamonds, $\mathrm{n}=4$ ) as a function of irradiance at the sediment surface ( $\mathrm{I}$ as photosynthetically available radiations, PAR) and adjusted models on immersion data (solid line, GCP $\left.=4.89\left(1-e^{-1 / 130}\right), R_{\text {raw }}^{2}=0.941, n=5, p<0.05\right)$ and on pooled data for immersion and emersion (dotted line, GCP $=4.87\left(1-\mathrm{e}^{-1 / 100}\right)\left(R_{\text {raw }}^{2}=0.947, n=9, p<0.001\right)$ 

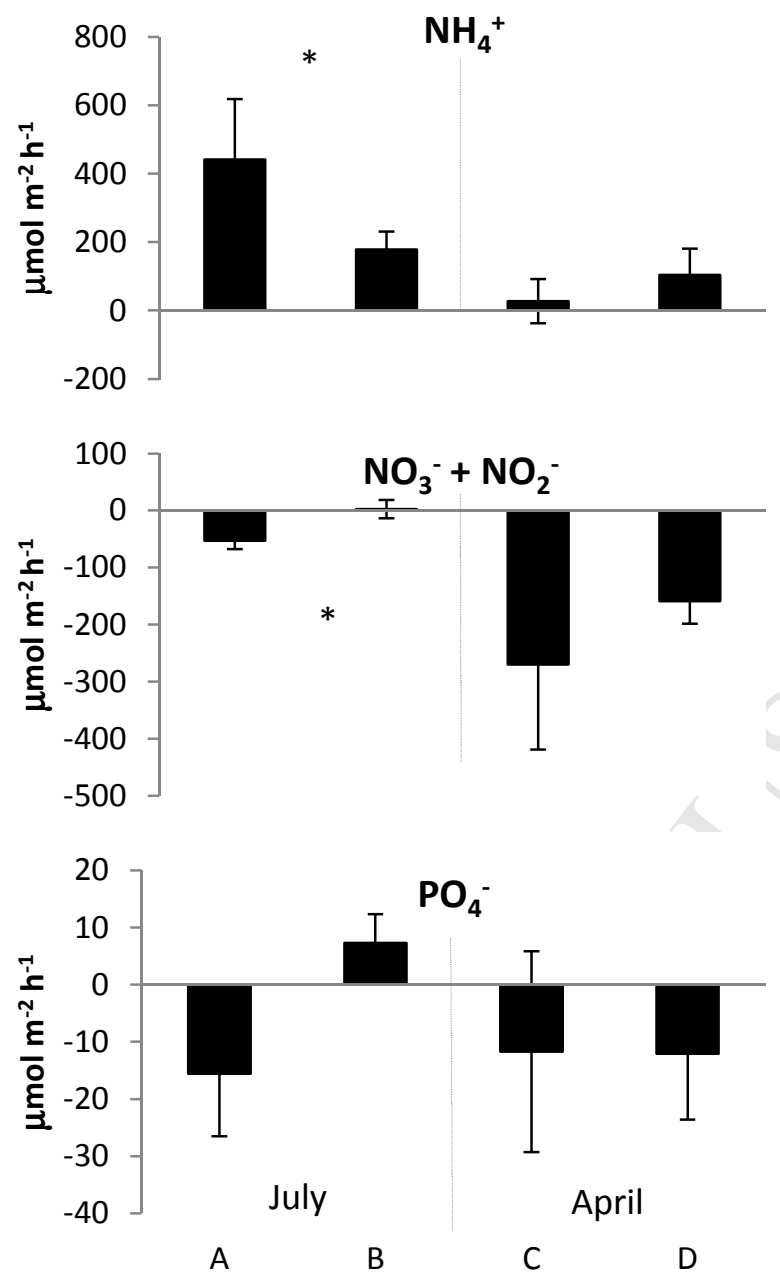

Figure 4: Mean $( \pm S E, n=3)$ nutrient fluxes (in $\left.\mu \mathrm{mol} \mathrm{m}^{-2} \mathrm{~h}^{-1}\right)$ measured in underwater dark incubations isolating sediment in the four visited stations (A \& B: July 2010, C \& D: April 2011). Asterisks indicate a significant difference between stations with $p \leq 0.05$ 